\title{
The Effect Of Service Quality, Product Quality, And Chatime Product Promotion On Customer Satisfaction
}

\author{
Ulfania Eka Erlinda ${ }^{1}$, Suryari Purnama ${ }^{2}$, Fachmi Tamzil ${ }^{3}$ \\ Universitas Esa Unggul, Jl. Arjuna Utara No 9, Jakarta, Indonesia \\ e-mail: ulfaniaeka@gmail.com ${ }^{1}$, suryari.purnama@esaunggul.ac.id ${ }^{2}$, \\ fachmi.tamzil@esaunggul.ac.id³
}

To cite this document :

Erlinda, U., Purnama, S. \& Tamzil, F (2022). The Effect Of Service Quality, Product Quality, And Chatime Product Promotion On Customer Satisfaction (ATM), 6(1), 42-51.

DOI :

https://doi.org/10.33050/atm.v6i1.1680

\begin{abstract}
This study aims to determine the effect of service quality, product quality, and promotion of Chatime products on customer satisfaction (case study of Chatime customers in the Central Jakarta Region). The population in this study were all consumers who made direct purchases at Chatime outlets in the Central Jakarta area during the Covid-19 pandemic. The population in this study is unknown or can be said to be in the infinite category. The sample in this study was taken by non-probability sampling method with purposive sampling technique as many as 185 respondents. The sampling criteria are consumers who have made direct purchases at Chatime outlets at least once in the last 6 months, female and male consumers who are at least 17 years old, respondents who are in the Central Jakarta area aged $>17$ years, have purchased and consumed Chatime for a minimum of 3 time. The method of data collection in this study was through an online questionnaire using google form. Data processing using Multiple Regression Analysis. Validity and reliability tests were carried out before distributing the final questionnaire. The results of this study indicate: (1) service quality has a positive and significant effect on customer satisfaction; (2) product quality has a positive and significant effect on customer satisfaction; (3) promotion has a positive and significant effect on customer satisfaction; (4) service quality, product quality, and promotion have a positive and significant effect simultaneously on Chatime customer satisfaction in the Central Jakarta area; (5) the variable that has a dominant influence on Chatime customer satisfaction in the Central Jakarta area is the promotion variable.
\end{abstract}

Keywords: Service Quality, Product Quality, Promotion and Customer Satisfaction

\section{Introduction}

2020 is the year when the Covid-19 pandemic is currently sweeping the world, and Indonesia is no exception. The number of cases of the Covid-19 virus is increasing every day, both in healing and death. Indonesian President Joko Wid odo announced on March 2, 2020, that Indonesia was affected by the Covid-19 virus and called ita non-natural disaster. The Indonesian government has taken various steps to contain the spread of the virus through various anticipatory measures, All activities must be carried out with physical distancing, mass and social distancing. This policy was issued to reduce the spread of Covid-19, which impacts all fields throughout Indonesia.

During the Covid-19 pandemic, this resulted in various zones, especially in the economic sector of the culinary industry, resulting in a drastic decrease in purchases [1][2]. Many companies experienced a decline in assets, so that several companies were finally forced to close their businesses. In this situation, the government finally implemented a "New Normal" to carry out activities usually. Still, it carried out health protocols to prevent transmission of the virus, such as using masks, washing hands, maintaining social distance[3]. 
Many beverage companies in Indonesia are increasingly competitive during this pandemic, such as Kokumi, Tiger Sugar, and Hop-Hop. As in the type of drink that will be explicitly discussed, namely Chatime. Chatime is a tea beverage supplierfrom Taiwan that offers more than 50 flavors of tea products. Chatime, which is located in Indonesia, is one of the units under the Kawan Lama Group company, which has been established since 2011[4]. Chatime has the concept of "Good Tea, Good Time," that the taste of the drinks produced by Chatime can be adjusted to the likes of all age groups from teenagers to adults.

The quality of service in business plays an essential role in maintaining customer satisfaction. If the quality of service provided to consumers is by their dreams, customers will be more satisfied and will carry out repurchases [5]. During this pandemic, the quality of service has changed a lot, such as always maintaining cleanliness when serving customers, using masks, using gloves, and always following health protocols. The emergence of a variety of new procedures throughout this pandemic will affect the services provided to consumers, so companies are obliged to improve efficient and efficient services to support customer satisfaction. Previous research by[6]stated that the service quality variable has a positive and signif icant effect on Grab customer satisfaction in Denpasar City.

The next thing that has significant meaning in a company is the product. With good product quality, it can fulfill customer desires so that it will create customer satisfaction. Companies that carry out product innovation will increase satisf action and repurchase the product. In addition, the Chatime products offered are required to maintain the cleanliness and safety of their products, so that product quality is maintained. Especially during this pandemic, with all the limitations that exist, Chatime must still innovate in its products. With the company developing its latest innovations and keeping the product clean, customers will feel satisfied.Based research conducted by [7] shows that there is a significant and positive effect between product quality and customer satisfaction the old champ.

In addition to service quality and product quality, promotion is also an aspect that affects customer satisfaction[8]. Promotional activities carried out by the company are said to be an effort to communicate a product to customers so that promotions carried out by the company can affect customer satisfaction. In the current pandemic, companies must seriously inform product promotions by using digital technology to market products and use social media to attract consumers. The current condition is that customers will have more time to access promotions from online media[9]. Of course, in this pandemic, promotion on social media is a way for companies to be still able to introduce their products today. As in[10], promotions positively and significantly affect customer satisfaction at PT Stainlessindo Anugrah Karya.

According to[11], the Chatime promotion at a low price created long queues during a pandemic. Chatime from 9 to 16 February 2021 makes a drink promotion for IDR 5,000. This has drawn criticism from various social media because the promo causes long queues, which are prohibited in a pandemic situation. Hence, customers regret the policies implemented because they are very negligent of health protocols. Customers regret that the queue is very crowded without any anticipation from the promo organizers because it has caused a dangerous impact on the community[12]. According to[13], there was a decline in the purchase of Chatime beverage products during the Covid-19 pandemic. The decrease in the purchase of Chatime drinks was due to the pandemic period, limiting people's mobilization and the government's recommendation to consume beverages produced at home.

Therefore, the importance of service quality, product quality, and promotion can positively impact and increase consumer satisfaction during the covid-19 pandemic, so Chatime seeks to find ways to create good performance in increasing customer satisfaction. The purpose of this study was to determine the influence of customers who buy Chatime related to service quality, product quality, and promotion to create customer satisfaction. .

\subsection{Tinjauan Pustaka Covid-19 pandemic}

According to [14], coronavirus is an inf ectious disease caused by a newly discovered virus. The coronavirus mainly spreads through saliva or nasal secretions when the person has coughs, runny noses, and sneezes.According to [3], the coronavirus can cause indications of respiratory disorders, fever above $38^{\circ} \mathrm{C}$, cough with phlegm, shortness of breath, and lethargy.

\section{Service Quality}

ATM Vol 6, No. 1 January 2022: 42-51 
Service quality is a determining aspect of making a purchase. The company views consumers as kings, so consumers must be served well to bring profit to the industry to survive. According to[15], service quality results from customer evaluation of the level of difference between what is expected and the perceived reality of the services that consumers receive from the industry. And according to[16], service quality is a form of activity carried out by organizations in delivering services that are in line with what consumers want, meaning services such as speed, convenience, relationships, friendliness, attitudes and abilities through the nature of providing satisfactory service to customers. According to[17], service quality indicators are as follows: (1) Physical form (Tangible), (2) Reliability, (3) Responsiveness, (4) Assurance, and (5) Empathy (empathy).

\section{Product quality}

Customers highly observe a quality product[18]. If the product is judged to meet or exceed, the customer will be satisfied with their desires and expectations. For[19], Product quality is product expertise to provide results and performance that match or exceed customer expectations. Furthermore, according to[20], product quality is a measure used to see the extent to which the products obtained can meet consumer desires and provide satisfaction to consumers. If the company succeeds in delivering products that meet consumer expectations, it will impact the industry's competitive advantage so that sales increase.[21]set product quality indicators as follows: (1) Performance quality, (2) Reliability, (3) Features, (4) Durability, and (5) Conformance Quality

\section{Promotion}

According to[10], Promotion is an organizational marketing mix element used to invite, inform and remind an organization's products. Promotion is an essential activity for companies. The aim is to introduce and educate consumers about the benefits of new products to persuade consumers to buy products to occur between buyers and sellers[22]. The purpose of introducing the production of goods is so that consumers can buy their products so that sales increase and increase company profits. The indicators in promotion, according to[23], are:

1. Advertising (advertising)

2. Sales promotion (sales promotion)

3. Personal selling (individual sales)

4. Public Relations (public relations), and Direct marketing (direct sales)

\section{Customer satisfaction}

In the business world, the ability to create and retain customers is essential to create customer satisfaction[24]. According to[19], satisfaction is a feeling of pleasure or disappointment in humans by equating the capabilities or results experienced from a product or service with dreams. Meanwhile, according to[25] consumer satisfaction is comparing perceptions or impressions of the performance of a company and its expectations which will result in feelings of liking or disappointment from consumers when they are satisfied with the product or service ordered or used by consumers who want to continue using the product or service that has been ordered provided. According to[26], the dimensions of consumer satisf action are as follows:

1. Feeling satisfied.

2. Always buying products.

3. I will recommend it to others.

4. Fulfillment of consumer expectations.

\subsection{Hypothesis Development}

\section{The influence of service quality on customer satisfaction}

Service quality has an important function in customer satisfaction, because good service quality in an industry will produce joy for its consumers. In previous research conducted by [27], it was stated that there was a positive and significant effect of service quality on consumer satisfaction. This means that quality service will be an attraction for consumers and will result in repeated purchases which will increase sales. The quality of service by the wishes or expectations of customers will increase customer satisfaction. Furthermore, [25]research argues that the service quality variable positively and significantly affects customer satisfaction. This means that the competence of employees in providing professional services to consumers is excellent so that

The Effect Of Service Quality, Product Quality, And Chatime Product Promotion On Customer Satisfaction (Ulfania Eka Erlinda) 
the quality of services offered can further increase customer satisfaction. This means that the presence of physical evidence, reliability, capture ability, assurance, and appropriate empathy in service quality can bring happiness to customers.

$\mathrm{H}_{1}$ : There is an influence of service quality on customer satisfaction

\section{Effect of product quality on customer satisfaction}

The quality of a product has a very significant role in shaping customer satisfaction[28]. In previous research by[29], that states product quality has a significant and positive effect on consumer satisfaction, so it means that the quality of a product is considered to be very closely related to customer satisfaction. Quality products can have a good influence on the company if consumers feel happy using the product to lead to customer satisfaction. Product quality can determine whether or not a company is good because by having good product quality, consumers will be interested in trying the product and will affect customer satisfaction. Furthermore, [30]proved that product quality positively and significantly affects consumer satisfaction, meaning that if the products provided by the industry are of good quality and meet consumer expectations, consumers are satisfied with the product, resulting in customer satisfaction. This result states that the higher the quality of a product provided by the company, the higher customer satisfaction will be.

$\mathrm{H}_{2}$ : There is an effect of product quality on customer satisfaction.

\section{Effect of promotion on customer satisfaction}

Promotion in a business is essential; without a business promotion, it is impossible to develop appropriately[31]. According to[21], the rise aims to encourage purchase frequency and demonstrations against potential consumers to feel satisfied and use the brand. In[32], it is explained that the promotion variable proves that there is a significant positive relationship effect on consumer satisfaction, stating that the more attractive the promotional activities of an industry, the more consumers will understand the products from the industry so that customers will feel satisfied in purchasing products. Furthermore, [33]research explains that the promotion variable significantly affects customer satisfaction. The results of his research explain that promotion with the internet, television, advertising media, and other media by the company will arouse consumer attention to the products offered to encourage customer satisfaction. The results of the study stated that the promotion had a positive or significant effect for customer satisfaction.

$\mathrm{H}_{3}$ : There is a promotion effect on customer satisfaction.

\section{The effect of service quality, product quality, and promotion on customer satisfaction}

Exogenous variables, namely service quality, product quality, and promotion, simultaneously affect customer satisfaction. In a previous study conducted by [20], it was stated that together the variables of service quality, product quality, and promotion can have a significant and positive influance on customer satisfaction. Conculuding that the better the quality of service, product quality, and promotion, the more customer satisfaction will be. That the quality of service, product quality and promotion have a very close relationship with customer satisfaction because the quality of service, product quality, as well as good promotions and as expected can encourage customers to continue to buy products so that it will create a sense of customer satisfaction and have a positive influence on company performance. While research by [34]that this study shows service quality, product quality, and promotion simultaneously have a significant and positive effect on consumer satisfaction.

$\mathrm{H}_{4}$ : There is an influence of service quality, product quality, and promotion on customer satisfaction.

\section{The most dominant influence of service quality on customer satisfaction}

Service quality has a very close relationship with customer satisfaction. In previous research conducted by[6], service quality has a dominant influence on customer satisfaction, meaning that if the service provided is good, it will dominate customers to continue to buy and create customer satisfaction. Furthermore, according to [35] states that service quality have the greatest impact in providing customer satisfaction, meaning that service is the most critical factor and is expected by customers in delivering customer satisfaction if the service provided is by customer expectations and desires, the service will continue to buy the product and will cause a feeling of satisfaction. Meanwhile, [36]explains that what has a more dominant influence on 
patient satisfaction is the service quality variable, meaning that quality services dominate to increase customer satisfaction. From various previous studies, service quality is the dominant influence of happiness and the desire to repurchase.

$\mathrm{H}_{5}$ : There is the most dominant influence of service quality on customer satisfaction

From the description above, the research model can be described as follows:

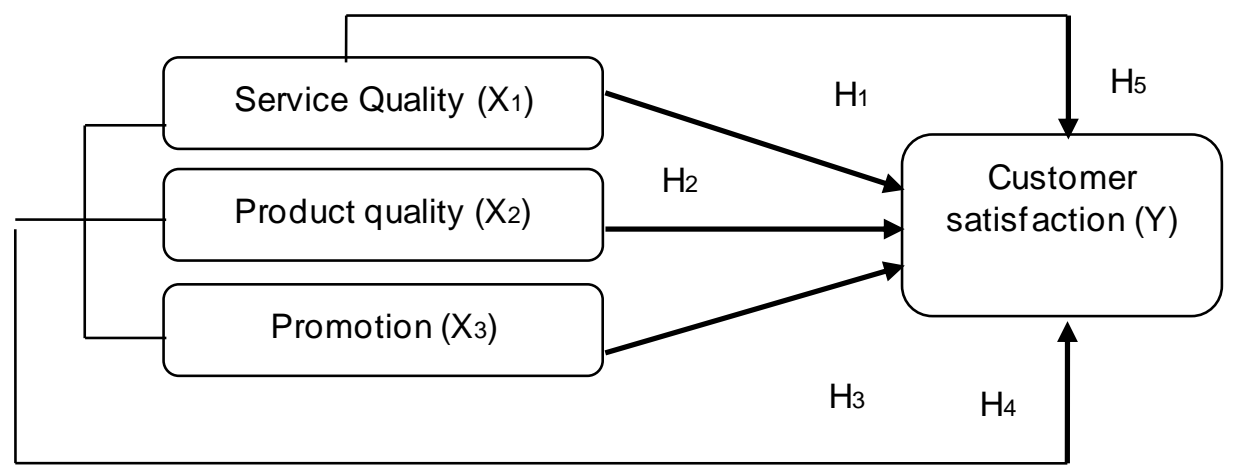

Figure 1. Research Model

\section{Research methodology}

The population of this research is Chatime customers who make direct purchases at Chatime outlets in the Central Jakarta area. By the analysis tool used, namely multiple regression, the determination of the number of samples in the numerous regression provisions is 5-10 times the number of questionnaires[37]. The number of questionnaire questions in this study was 37 , so the number of samples in this study (37x5) was 185 Chatime customers, provided that customers who had made direct purchases at Chatime outlets at least 1 time in the last 6 months, female and male consumers who were at least 17 years old and respondents residing in the Central Jakarta area. Furthermore, This research design uses quantitative research, and there are exogenous variables (service qualiity, product qualiity, promotions), endogenous variables (customer satisfaction). Multiple regression analysis methods are used to see whether or not there is an influence between one or more exogenous variables and endogenous variables.

Measurements in the research for service quality variables adopted from[19], product quality variables adopted from[21], then promotion measurements adopted from[19], and customer satisfaction was measured by adopting in[26]. This study is data obtained a questionnaire using the Likert scale method.. Furthermore, the validity test was carried out on 30 respondents using Product Moment by comparing the correlation index if $r_{\text {count }}>r$ table, with $r$ table (0.316) showing good validity. Likewise, the reliability test of Cronbach's alpha value $>0.6$ indicates good reliability.

\section{Results and Analysis}

\subsection{Results Analysis with Multiple Regression}

This study focuses on Chatime customers who make direct purchases at Chatime outlets in the Central Jakarta area as many as 185 samples as respondents. The results of multiple regression analysis with SPSS software show that the first analysis is the measurement of the validity test in this study showing all variable indicators (service quality, product quality, and promotion) can be accepted provided that the T value is valid $(>1.973)$ and the significant value $(<0.05)$ at the 0.05 level of significance. The results of the reliability test are eligible if Cronbach's alpha $(>0.6)$ and the results show all reliable variables with the value of Cronbach's alpha service quality $(0.893)$, product quality $(0.848)$, promotion $(0.858)$, and customer satisfaction $(0.876)$.

The second analysis is the structural test by looking at the value of $R$ square, showing how far the independent variable can explain the dependent variable, together with service quality, product quality, and promotion affect customer satisfaction with an $\mathrm{R}$ square value of 0.502 . This 
means that $50.2 \%$ of the variance of customer satisfaction can be interpreted by the variables of service qualilty, product quality, and promotion.

The third analysis, namely the $F$ test analysis, basically aims to show whether all exogenous variables included in the model have a simultaneous influence on endogenous variables. The results state that $F$ count $60.767>\mathrm{f}$ table 2.65 and significant $<0.05$ means $\mathrm{H}_{4}$ is accepted. It was concluded that the variables of service quality, product quality, and promotion had a simultaneous positive and significant effect on the variable customer satisfaction Chatime in the Central Jakarta area.

The fourth analysis is seen from the test by comparing $t$ count with $F$ table using a significant value of 0.05 and sig $t<0.05$, indicating the service quality variable has a $t$ count of $2.196>t$ table of 1.973 with a significant level of $0.029<0.05$ meaning $\mathrm{H}_{1}$ is accepted, it is concluded that the service quality variable has a positive and partially significant effect on customer satisfaction. The $t$ test results on the product quality variable have a $t$ count of $2.844>t$ table of 1.973 with a significant level of $0.005<0.05$, meaning $\mathrm{H}_{2}$ is accepted, which means that the product quality variable has a positive and partially significant effect on customer satisfaction. The t test results on the promotion variable have a $t$ count of $6.160>t$ table of 1.973 with a significant level of $0.000<0.05$, meaning $\mathrm{H}_{3}$ is accepted. It is stated that the promotion variable has a positive and partially significant effect on customer satisfaction. The results show that promotion has a dominant impact on customer satisfaction with the most significant beta value of 0.429 and the smallest considerable value of 0.000 , which means $\mathrm{H}_{3}$ is rejected that service quality is not proven to be the most dominant variable. Furthermore, the model from the research results can be seen as follows:

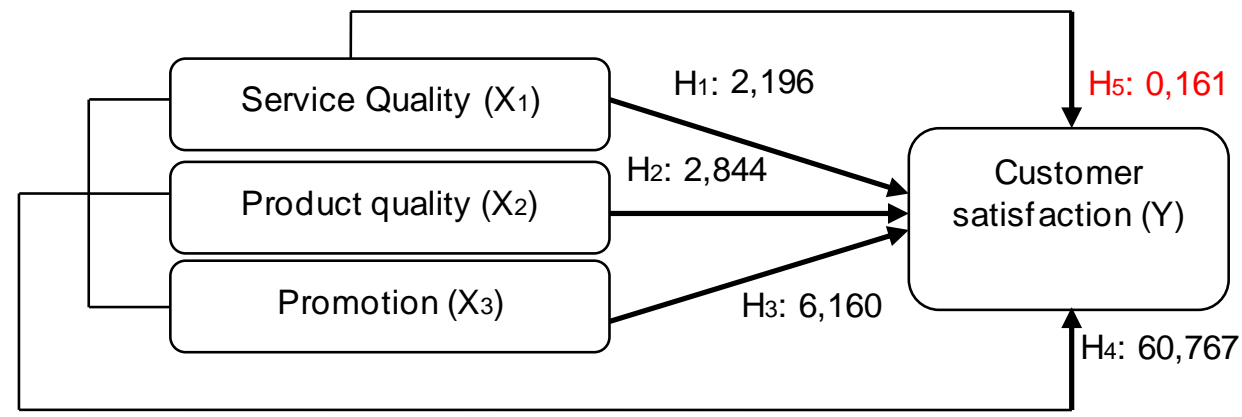

Figure 2. Research Model Results

Based on Figure 2, the results of this hypothesis can be seen in the following table:

Table 1. Hypothesis Testing Results

\begin{tabular}{|c|c|c|c|c|}
\hline Hypothesis & Hypothesis Statement & $\begin{array}{l}\text { T-Value } \\
(>1,973)\end{array}$ & $\begin{array}{l}\text { Significant } \\
\text { Value } \\
(<0.05)\end{array}$ & Information \\
\hline $\mathrm{H}_{1}$ & $\begin{array}{l}\text { The influence of service } \\
\text { quality on customer } \\
\text { satisfaction }\end{array}$ & 2,196 & 0,029 & Be accepted \\
\hline $\mathrm{H}_{2}$ & $\begin{array}{l}\text { Effect of product quality on } \\
\text { customer satisfaction }\end{array}$ & 2,844 & 0,005 & Be accepted \\
\hline $\mathrm{H}_{3}$ & $\begin{array}{l}\text { Effect of promotion on } \\
\text { customer satisfaction }\end{array}$ & 6,160 & 0,000 & Be accepted \\
\hline Hypothesis & Hypothesis Statement & $\begin{array}{c}\text { F-Value } \\
(>2,65)\end{array}$ & $\begin{array}{l}\text { Significant } \\
\text { Value } \\
(<0.05) \\
\end{array}$ & Information \\
\hline $\mathrm{H}_{4}$ & $\begin{array}{l}\text { The effect of service quality, } \\
\text { product quality, and promotion } \\
\text { on customer satisfaction }\end{array}$ & 60,767 & 0,000 & Be accepted \\
\hline Hypothesis & Hypothesis Statement & $\begin{array}{c}\text { Beta } \\
\text { (largest) }\end{array}$ & $\begin{array}{c}\text { Significant } \\
\text { Value } \\
\text { (smallest) }\end{array}$ & Information \\
\hline
\end{tabular}




\begin{tabular}{|l|l|l|l|l|}
\hline $\mathrm{H}_{5}$ & $\begin{array}{l}\text { The service quality variable } \\
\text { has the greatest impact on } \\
\text { customer satisfaction }\end{array}$ & 0,161 & 0,029 & Rejected \\
\hline
\end{tabular}

\subsection{Discussion}

The results of the first hypothesis test show that service quality variables affect Chatime customer satisfaction. This indicates that the higher the quality of service provided by Chatime to customers, the greater the level of customer satisfaction. Customers feel that the courteous and friendly service provided when interacting between sellers and customers is an attitude that customers need to encourage consumers to make purchases. By applying applicable Standard Operating Procedures such as using masks and wearing gloves, customers are satisfied to provide positive values. To the services of fered. Providing good service can form a perception in the minds of customers that the company has good credibility. However, if there is a failure in service quality, it will not affect customer satisfaction if the loss is quickly repaired and resolved accurately and rapidly. According to previous research by [38], [39] and [40] it is argued that service quality has a major influence on customer satisfaction.

The results of the second test explain that the product quality variable has an effect on Chatime's customer satisfaction. This indicates that the better the quality of the products offered by Chatime to customers, the better the level of customer satisfaction with Chatime products. Customers prioritize products that have been certified halal because they believe that the product is safe for consumption. Taste is also a critical aspect that customers pay attention to in buying drinks. Chatime has many flavor variants and is delicious and clean, so customers will feel satisfied to continue to buy without worrying about the products they drink.

Most importantly, during this pandemic, Chatime really maintains the cleanliness and saf ety of packaging according to health. If the product matches the expectations and expectations of the customer, the customer will give a good evaluation of the product. With this evaluation, the customer will feel satisfied and still want to buy the product. These results are from previous research by [41] and [42] that product quality has a significant and positive effect on satisfaction.

The results of the third test prove that promotions affect Chatime's customer satisfaction. The more attractive the rise, the better the level of customer satisfaction. By promoting products using advertisements, customers can find out about new events and products organized by Chatime to bring in new consumers or influence the repurchase of these products. Providing many discounts can benefit customers to create consumer satisfaction, and customers will continue to buy these products. Especially in this pandemic period, with limited customer mobilization, online media is one of the most effective promotional events. Chatime also conducts online transactions so that it accepts payments via digital wallets. Digital wallets also provide many discounts. Online transactions also affect customer satisfaction[31]. This shows that respondents prioritize promotion as a medium to inform and encourage consumers to buy products. These results support [43], [44] and [45] results which state that promotion is the most important factor affecting customer satisfaction.

The results of the fourth hypothesis state that service quality, product quality, and promotion simultaneously affect Chatime's customer satisfaction. Customer satisfaction is created if the quality of service, product quality, and advertisements provided is by consumer expectations. It can be interpreted that if the quality of service, product quality, and promotion increases, customer satisfaction continues to increase. This states that impressive service quality can attract customers. This means that high-quality services will also affect the feeling of satisfaction for customers and the occurrence of repeat purchases to increase sales.

Furthermore, suppose the product received by consumers has the desired reliability or advantage. In that case, consumers will value the development and continue to buy the products of fered to create customer satisf action and engage in promotional activities by providing discounts that can increase customer satisfaction and sales. These results are from previous research by [46] of [47] and [48] that service quality, product quality and promotion affect customer satisfaction.

Furthermore, testing the fifth hypothesis concluded that promotion is the most dominant variable affecting consumer satisfaction at Chatime. Promotion affects customer satisfaction because consumers will be attracted by attractive offers and can fulfill the desire to repurchase the product. This invalidates the hypothesis (H5), which states that service quality has the most dominant and insignificant effect. The significant result is the most dominant promotion variable.

The Effect Of Service Quality, Product Quality, And Chatime Product Promotion On Customer Satisfaction (Ulfania Eka Erlinda) 
This result is not by [6] explain that service quality most dominantly affects customer satisfaction. But this supports previous research, namely [49], with the result that has the most decisive influence is promotion. Furthermore, the same as the research according to [50] which states that the promotion variable has a dominant effect on customer satisfaction.

\section{Conclusions}

Based on the above results, it can be concluded that (1) service quality affects Chatime's customer satisfaction, which means that the more comfortable and good Chatime services are, the more customer satisf action will be; (2) product quality affects Chatime's customer satisfaction. This means that the better the quality of Chatime's products and the right advantages, the Chatime customers will be satisfied with what they get; (3) promotion affects customer satisfaction Chatime. With the more attractive promotions the company applies to consumers, Chatime provides many discounts and promotions on social media, the more satisfying customers will be; (4) service quality, product quality, and promotions together affect Chatime's customer satisfaction; (5) shows that the dominant influence on Chatime customer satisfaction is promotion. It was concluded that the hypothesis $\left(\mathrm{H}_{5}\right)$, which stated that service quality $\left(\mathrm{X}_{2}\right)$ had the most dominant effect, was not proven. Furthermore, some suggestions are taken into consideration for Chatime to be input. It is recommended that Chatime improve the quality of service faster because, with fast service, customers are satisfied. It is recommended that Chatime enhance the quality of products related to the durability of Chatime's products. It is recommended that the promotions offered can be maintained by providing many discounts to be more interested in buying the product. Forfurther researchers, it is hoped that expanding the population will increase other variables besides service quality, product quality, and promotions that can affect customer satisfaction with additional analyses to increase knowledge insight to obtain better results.

\section{Referensi}

[1] S. Sayyida, S. Hartini, S. Gunawan, and S. N. Husin, "The Impact of the Covid-19 Pandemic on Retail Consumer Behavior," Aptisi Trans. Manag., vol. 5, no. 1, pp. 79-88, 2021.

[2] B. E. Sibarani, "Smart Farmer Sebagai Optimalisasi Digital Platform Dalam Pemasaran Produk Pertanian Pada Masa Pandemi Covid-19," Technomedia J., vol. 6, no. 1, 2021.

[3] Kementrian, "Kementrian Kesehatan," 2020.

[4] Chatimelndonesia, "Chatime Indonesia," Chatimelndonesia.com, 2020.

[5] S. Sutirna, "Total Quality Management Through Lecturer Assessment With Students To Improve Graduate Quality," ADI J. Recent Innov., vol. 2, no. 1 Sept, pp. 227-242, 2020.

[6] D. G. W. Santosa and I. A. Mashyuni, "Pengaruh Promosi dan Kualitas Pelayanan terhadap Kepuasan Pelanggan Grab di Kota Denpasar," Widya Amrita J. Manajemen, Kewirausahaan dan Parwisata, vol. 1, no. 1, pp. 290-302, 2021.

[7] K. A. G. K. Putra and N. K. Seminari, "Kualitas Produk, Kualitas Layanan, dan Kewajiban Harga Berpengaruh Terhadap Kepuasan Pelanggan The Old Champ Cafe," E-Jurnal Manaj., vol. 9, no. 10, pp. 3423-3442, 2020.

[8] D. Abdullah, U. Rahardja, and F. P. Oganda, "Covid-19: Decentralized Food Supply Chain Management," Syst. Rev. Pharm, vol. 12, no. 3, pp. 142-152, 2021.

[9] N. Adiyanto, "Customer Relationship Management (CRM) Based On Web To Improve The Performance Of The Company," ITSDI J. Ed. Vol. 1 No. 1 Oct. 2019, p. 32, 2019.

[10] V. Adriani and Realize, "Pengaruh Kualitas Pelayanan dan Promosi Terhadap Kepuasan Pelanggan pada PT Stainlessindo Anugrah Karya di Kota Batam," J. Pundi, vol. 2, no. 2, pp. 169-180, 2018, doi: 10.31575/jp.v2i2.78.

[11] Kumparan, "Viral Promosi Minuman Goceng Chatime Bikin Antrean Panjang di Tengah Pandemi," Kumparan, 2021.

[12] H. E. Sari and R. Prasetiawati, "Analisis Sistem Informasi Customer Relationship Management Berbasis Web Pada PT. Inovatif Teknik Mesindo: ID," Technomedia J., vol. 5, no. 1 Agustus, pp. 1-13, 2020.

[13] D. Tungka, M. M. Lionardo, S. Thio, and V. Iskandar, "Pengaruh Social Media Marketing Pada Instagram Terhadap Minat Beli Chatime Indonesia," J. Hosp. dan Manaj. Jasa, vol. 8, no. 2, pp. 77-87, 2020.

[14] W. H. Organization, "World Health Organization," 2020.

[15] H. Al Rasyid, "Pengaruh Kualitas Layanan Dan Pemanfaatan Teknologi Terhadap 
Kepuasan Dan Loyalitas Pelanggan Gojek," J. Ecodemica, vol. 1, no. 2, pp. 211-223, 2017.

[16] R. P. Christian and L. Mananeke, "Pengaruh Strategi Promosi Dan Kualitas Layanan Terhadap Kepuasan Pelanggan Pengguna Bpjs Di Rsud Sam Ratulangi Tondano," J. $E M B A$, vol. 121, no. 2, pp. 121-132, 2016.

[17] F. Tjiptono and G. Chandra, Service, Quality \& Satisfaction. Yogyakarta: Edisi 4. Yogyakarta: Andi, 2016.

[18] R. Aulia, A. Sururi, and S. Sukendar, "Effectiveness Of Featured Product Of Rural Areas Program (Prukades) In Improving The Economy Of Teluk Village Community Pandeglang Regency," ADI J. Recent Innov., vol. 2, no. 1 Sept, pp. 204-211, 2020.

[19] F. Tjiptono and A. Diana, "Pemasaran," 2020.

[20] D. K. Sari and S. Paludi, "Pengaruh Kualitas Pelayanan, Kualitas Produk, dan Promosi Terhadap Kepuasan Pelanggan di Restoran Uccello," Maj. IIm. Panor. Nusant., vol. 15, no. 1, 2020.

[21] H. B. H. Havidz and M. R. Mahaputra, "Brand Image And Purchasing Decision: Analysis Of Price Perception And Promotion (Literature Review Of Marketing Management)," Dinasti Int. J. Econ. Financ. Account., vol. 1, no. 4, pp. 727-741, 2020.

[22] I. G. Q. Ngalimin, W. J. F. A. Tumbuan, and Y. Mandagie, "Strategi Relationship Marketing Dan Promosi Pengaruhnya Terhadap Kepuasan Konsumen Di Matahari Departement Store Mega Mall Manado," J. EMBA, vol. 7, no. 1, pp. 571-580, 2019.

[23] P. Kotler and G. Amstrong, Prinsip - Prinsip Pemasaran. Jakarta: Edisi 13. Jakarta: Erlangga, 2016.

[24] T. Mariyanti, P. Edastama, and M. H. M. Shafiai, "Factors Affecting Islamic Bank Customer Satisfaction," Aptisi Trans. Manag., vol. 5, no. 2, pp. 152-160, 2021.

[25] M. Aulia and I. Hidayat, "Pengaruh Kualitas Produk, Kualitas Pelayanan Dan HArga Terhadap Kepuasan Konsumen Amanda Brownies," J. Chem. Inf. Model., vol. 6, no. 9, pp. 1-17, 2017.

[26] S. Dadang, "Pengaruh Harga, Kualitas Produk dan Kualitas Layanan Terhadap Kepuasan Konsumen di PT. Honda Autobest Bandung," Open J. Syst., vol. 14, no. 3, pp. 2539-2548, 2019.

[27] M. H. Gery, "Pengaruh Kualitas Pelayanan, Lokasi Dan Promosi Terhadap Kepuasan Konsumen the Aliga Hotel Padang," Menara ilmu, vol. 12, no. 9, pp. 92-102, 2018.

[28] A. Juheti and E. Sulaeman, "Effect of Work Discipline and Compensation on the Performance of Employees of Subang District Trade and Industrial Cooperative Office," Aptisi Trans. Manag., vol. 5, no. 2, pp. 128-136, 2021.

[29] B. Tombeng, F. Roring, and F. S. Rumokoy, "Pengaruh Kualitas Pelayanan, Harga, dan Kualitas Produk Terhadap Kepuasan Konsumen Pada Rumah Makan Raja Oci Manado," J. EMBA J. Ris. Ekon. Manajemen, Bisnis dan Akunt., vol. 7, no. 1, pp. 891-900, 2019.

[30] F. S. Maramis, J. L. Sepang, and A. S. Soegoto, "Pengaruh Kualitas Produk, Harga, dan Kkualitas Pelayanan Terhadap Kepuasan Konsumen Pada PT. Air Manado," EMBA, vol. 6, no. 3, pp. 1658-1667, 2018.

[31] S. Purnama, C. S. Bangun, and S. A. Faaroek, "The Effect of Transaction Experience Using Digital Wallets on User Satisfaction in Millennial Generation," Aptisi Trans. Manag., vol. 5, no. 2, pp. 161-168, 2021, doi: 10.33050/atm.v5i2.1593.

[32] M. A. Roselina and A. Niati, "Analisis Pengaruh Kualitas Produk, Kualitas Pelayanan, Dan Promosi Terhadap Kepuasan Konsumen," Majalah IImiah Solusi, vol. 17, no. 3, pp. 221234, 2019.

[33] R. Madjukie and L. Harjati, "Pengaruh Promosi Dan Kualitas Layanan Terhadap Kepuasan Konsumen Zalora Indonesia Jakarta," J. Manaj., vol. 7, no. 2, pp. 124-137, 2018.

[34] G. B. Nurlia and Mahmud, "Pengaruh Kualitas Produk, Promosi Dan Kualitas Pelayanan Terhadap Kepuasan Konsumen Toko Kiyomi Jeans Di Itc Cempaka Mas Jakarta Pusat," IKRA-ITH Ekon., vol. 4, no. 2, pp. 31-40, 2021.

[35] I. Maulidah, J. Widodo, and M. Zulianto, "Pengaruh Kualitas Produk Dan Kualitas Pelayanan Terhadap Kepuasan Konsumen Di Rumah Makan Ayam Goreng Nelongso Jember," J. Pendidik. Ekon. J. IIm. IImu Pendidikan, IImu Ekon. dan IImu Sos., vol. 13, no. 1, pp. 26-29, 2019, doi: 10.19184/jpe.v13i1.10416.

[36] Suyitno, "Analisis Pengaruh Kualitas pelayanan, Penetapan Harga dan Fasilitas Terhadap Kepuasan Pasien (Studi Pada Pasien Rumah Sakit Umum Daerah (RSUD) di Kabupaten 
Malang)," J. Appl. Bus. Adm., vol. 2, no. 1, pp. 129-143, 2018.

[37] J. F. Hair, W. C. Black, B. J. Babin, and R. E. Anderson, Multivariate Data Analysis. Pearson Prentice Hall, 2010.

[38] A. Tandiono and Raymond, "Pengaruh Kualitas Pelayanan dan Kualitas Promosi Terhadap Kepuasan Pelanggan Pada PT Panca Daya Sukses," J. EMBA, vol. 8, no. 1, pp. 1997-2006, 2020.

[39] N. Arianto, "Pengaruh Promosi Dan Kualitas Pelayanan Terhadap Kepuasan Serta Berdampak Terhadap Loyalitas Pelanggan," J. IIm. Prodi Manaj. Univ. Pamulang, vol. 7, no. 1, pp. 44-54, 2019, [Online]. Available: KREATIF Jurnal Ilmiah Prodi Manajemen Universitas Pamulang, Volume 7, No 1 Juni 2019.

[40] G. P. Yohana and A. L. Andjarwati, "Pengaruh Kualitas Layanan Dan Harga Terhadap Kepuasan Dan Loyalitas Pelanggan (Studi Pada Pelanggan Medin Beauty)," J. IImu Manaj., vol. 5, no. 3, pp. 1-9, 2017.

[41] D. G. Zakaria, "Pengaruh Kualitas Pelayanan, Kualitas Produk dan Harga Terhadap Kepuasan Pelanggan," IImu dan Ris. Manajemen, ISSN 2461-0593, vol. 6, no. 4, pp. 118, 2017.

[42] Y. A. Sinaga, F. A. Hayati, and U. Chasanah, "Pengaruh Kualitas Produk Dan Kualitas Pelayanan Terhadap Kepuasan Pelanggan Pada Rich Perfumery ITC Kuningan Jakarta Selatan," J. IIm. Feasible, vol. 3, no. 1, pp. 54-60, 2021.

[43] R. W. Sihite and N. P. Nainggolan, "Pengaruh Kualitas Pelayanan Dan Promosi Terhadap Kepuasan Pelanggan di Alfamart Marchelia Batam,” J. Abdi IImu, vol. 13, no. 1, pp. 3541, 2020.

[44] I. M. A. Andreanata and I. I. D. A. Y. Wilyadewi, "Pengaruh Promosi dan Kualitas Produk terhadap Kepuasan Pelanggan pada UD. Sari Jaya Buah kabupaten Bandung," J. Widya Amrita, J. Manajemen, Kewirausahaan dan Pariwisata, vol. 1, no. 1, pp. 14-24, 2021.

[45] S. Rezeki, D. E. Maryati, and M. Rinaldi, "Pengaruh Kualitas Pelayanan Dan Promosi Terhadap Kepuasan Pelanggan OVO (Studi Kasus Pada Mahasiswa STIE Eka Prasetya)," J. Manaj. Bisnis Eka Prasetya Penelit. IImu Manaj., vol. 6, no. 2, pp. 9-20, 2020, doi: 10.47663/jmbep.v6i2.71.

[46] N. Efendi, S. O. Ginting, and J. Halim, "Citra Merek, Kualitas Produk, Promosi, Kualitas Pelayanan Dan Kepuasan Konsumen,” J. IImu Ekon. Sos., vol. 11, no. 2, pp. 102-112, 2020.

[47] P. Simanjuntak and T. Purba, "Pengaruh Kualitas Produk, Kualitas Pelayanan dan Promosi terhadap Tepuasan Konsumen Holland Bakery Di Kota Batam," J. Manag. Accounting, Econ. Bus., vol. 01, no. 02, pp. 315-329, 2020.

[48] N. Rochman, M. Hufron, and S. Asiyah, "Pengaruh Kualitas Produk,Kualitas Pelayanan Dan Promosi Pada Uniccrab Seafood Malang Terhadap Kepuasan Konsumen," J. Ris. Manaj., vol. 9, no. 18, pp. 1-15, 2020.

[49] E. K. Hamdun and D. A. Romadhani, "Pengaruh Produk, Harga dan Promosi Terhadap Kepuasan Konsumen Pada Toko Roti Fatimah Bakery Di Situbondo," Growth, vol. 14, no. 2, pp. 31-48, 2019.

[50] M. F. T. Adi, Sutopo, and I. Noviandari, "Pengaruh Promosi, Harga, dan Kualitas Pelayanan terhadap Kepuasan Konsumen pada Layanan Gofood Gojek Dikawasan Rungkut Surabaya (Studi Kasus Konsumen Gofood Gojek Dikawasan Rungkut Surabaya)," UBHARA Manag. J., vol. 1, no. 2, pp. 293-300, 2021. 